\title{
AMINO ACID-BASED FERTILIZER AS AN ALTERNATIVE TO CALDA VIÇOSA IN ORGANIC AGRICULTURE
}

\author{
Diego Fontebasso Pelizari Pinto ${ }^{1,2}$, Sergio Kenji Homma ${ }^{1}$, Betânia Roqueto dos Reis ${ }^{1}$, Rodrigo \\ Henriques Longaresi ${ }^{1}$, Juliana Cristina Scotton ${ }^{1}$, Amália Aparecida Busoni Campos ${ }^{1}$, Wesley Luiz \\ Fialho Costa ${ }^{1}$
}

\begin{abstract}
The aim of this study was to propose a mixture of micronutrients with amino acid-based foliar fertilizer as an alternative to calda viçosa for application in organic agriculture. The study was conducted in two simultaneous trials in an experimental field in Ipeúna, SP, Brazil. The test plant was carioca type dry edible bean cv. Pérola. The treatments in trial 1 were: Control $1=$ water; FA $=\mathrm{JK} \otimes$ amino acid-based foliar fertilizer; and $\mathrm{FA}+\mathrm{Mi}=\mathrm{FA}+\mathrm{CuSO}_{4}+\mathrm{ZnSO}_{4}+\mathrm{MnSO}_{4}+\mathrm{H}_{3} \mathrm{BO}_{3}$. In trial 2, the FA treatment was substituted by calda viçosa $(\mathrm{CVi})$. The treatments were through spray application three times. Dry edible bean leaves were sampled for determination of macronutrient and micronutrient concentrations. Platings of the application rates used in the treatments were performed in the laboratory in a mixture with Bacillus thuringiensis and with Beauveria bassiana to compare the degree of compatibility by means of colony forming units (CFU). The FA+Mi and CVi treatments raised the concentrations of $\mathrm{Zn}, \mathrm{Cu}$, and $\mathrm{Mn}$ in the leaves. The FA+Mi was compatible, the FA was a stimulant, and the CVi was noxious to B. bassiana and to B. thuringiensis when integrated in the spray mixture.
\end{abstract}

Keywords: Bacillus thuringiensis, Beauveria bassiana, copper, manganese, zinc.

\section{FERTILIZANTE A BASE DE AMINOÁCIDOS COMO ALTERNATIVA À CALDA VIÇOSA NA AGRICULTURA ORGÂNICA}

\begin{abstract}
RESUMO - O trabalho objetivou propor a mistura de micronutrientes com fertilizante foliar a base de aminoácidos como alternativa à calda viçosa para aplicação na agricultura orgânica. O estudo foi conduzido em dois ensaios simultâneos em campo experimental em Ipeúna - SP. A planta teste foi o feijoeiro tipo carioca cultivar Pérola. O ensaio 1 teve como tratamento: Controle 1 = água; FA = fertilizante foliar $\mathrm{JK}{ }^{\circledR}$ a base de aminoácidos; $\mathrm{FA}+\mathrm{Mi}=\mathrm{FA}+\mathrm{CuSO}_{4}+\mathrm{ZnSO}_{4}+\mathrm{MnSO}_{4}+\mathrm{H}_{3} \mathrm{BO}_{3}$. No ensaio 2 substituiuse o tratamento FA pela calda viçosa (CVi). Os tratamentos foram pulverizados três vezes. Folhas do feijoeiro foram amostradas para determinação dos teores dos macronutrientes e micronutrientes. Em laboratório foram feitos os plaqueamentos das doses utilizadas dos tratamentos, em mistura ao Bacillus thuringiensis e ao Beauveria bassiana para comparar o grau de compatibilidade por meio de unidades formadoras de colônia (UFC). Os tratamentos FA+Mi e CVi elevaram os teores de $\mathrm{Zn}$, Cu e Mn nas folhas. O FA+Mi foi compatível, o FA foi estimulante e a CVi foi nociva ao B. bassiana e o B. thuringiensis, quando misturados à calda de aplicação.
\end{abstract}

Palavras-chave: Bacillus thuringiensis. Beauveria bassiana, cobre, manganês, zinco.

\footnotetext{
${ }^{1}$ Centro de Pesquisa Mokiti Okada, Setor de Pesquisa em Manejo de Solo e Planta, diego.pelizari@cpmo.org.br.

${ }^{2}$ Escola Superior de Agricultura Luiz de Queiroz - Universidade de São Paulo, Programa de Pós Graduação Solos e Nutrição de Plantas.
} 


\section{INTRODUCTION}

The demand for organic food has increased each year throughout the world, which has driven research especially related to this type of agriculture (Dias et al., 2015). Consumer demand for foods free of agricultural chemicals has generated a $51.7 \%$ increase in the number of organic producers certified in Brazil (Carvalho Júnior \& Hauffe, 2013; Brasil, 2015). Thus, studies are required to verify the efficiency of new alternatives for managing fertilization and plant health in these systems to ensure market supply.

The use of calda viçosa (a mixture of copper, zinc, and magnesium sulfate, boric acid, and lime) is a management technique widely used and recognized by organic farmers in Brazil. It is a derivation of calda bordalesa (lime and copper sulfate), which has bactericidal and fungicidal action, with the addition of nutrients (Aquino et al., 2008; Androcioli et al., 2012; ; Silva, 2012; Carvalho et al., 2015) and has the function of protecting and nourishing the plant. However, organic agriculture is a systemic science and the plant health objective of this mixture is not in agreement with environmental balance because the mixture is not selective for plant pathogenic microorganisms and can interfere in the beneficial microbiota of the system (Nix-stohr et al., 2007; Montalba et al., 2010; Pozzebon et al., 2010). These beneficial microorganisms include entomopathogenic bateria and fungi. They are regularly used in organic farming through commercial products and are frequently mixed with spray applications or fertigation, with the goal of decreasing operating costs.

$\mathrm{JK} \otimes$ is a commercial organic fertilizer applied on leaves and classified as a Class A Fluid Foliar Compound. This fertilizer is obtained from controlled fermentation of fish residues with sugarcane molasses (used as a pre-biotic). The final product contains diverse amino acids and sugars derived from molasses that can be utilized by the plant or other organisms of the agricultural system (Newton et al., 2010).

With these characteristics, it is possible that $\mathrm{JK}$ acts as a vehicle of nutrients in a manner less aggressive to the entomopathogenic organisms that should be preserved in the system.

The aim of the study was to propose a mixture of micronutrients with amino acid-based foliar fertilizer as an alternative to calda viçosa for application in organic agriculture.

\section{MATERIALS AND METHODS}

The study was conducted in two simultaneous trials in an experimental field ( $22^{\circ} 23^{\prime} 58^{\prime \prime} \mathrm{S} ; 47^{\circ} 40^{\prime} 56^{\prime \prime}$ W) in the municipality of Ipeúna, SP, Brazil. The crop used was carioca (beige with brown stripes) type dry edible bean cv. Pérola. The soil is classified as a Latossolo Vermelho eutrófico with clayey texture (Embrapa, 2006). The climate in the region is Cwa, according to Köppen, hot and humid, with a dry winter and altitude of 635 $\mathrm{m}$ AMSL. The area has been cultivated with organic agriculture techniques since 1991, with diverse horticultural crops and grains. Over this period, the area has not received the addition of fertilizer or soil amendments.

The soil was previously sampled for chemical analysis according to the methodology of Raij et al. (2001) and exhibited the following results: $\mathrm{pH}\left(\mathrm{CaCl}_{2}\right)=5.9, \mathrm{OM}=$ $29.7 \mathrm{~g} \mathrm{dm}^{-3}, \mathrm{P}=64.8 \mathrm{mg} \mathrm{dm}^{-3}, \mathrm{Ca}=64.5 \mathrm{mmol}_{\mathrm{c}} \mathrm{dm}^{-3}, \mathrm{Mg}$ $=34.4 \mathrm{mmol}_{\mathrm{c}} \mathrm{dm}^{-3}, \mathrm{~K}=9.6 \mathrm{mmol}_{\mathrm{c}} \mathrm{dm}^{-3}, \mathrm{H}+\mathrm{Al}=24 \mathrm{mmol}_{\mathrm{c}}$ $\mathrm{dm}^{-3}, \mathrm{CEC}=132.5 \mathrm{mmol}_{\mathrm{c}} \mathrm{dm}^{-3}, \mathrm{~V} \%=81.9 \%, \mathrm{Cu}=3.3 \mathrm{mg}$ $\mathrm{dm}^{-3}, \mathrm{Fe}=26.2 \mathrm{mg} \mathrm{dm}^{-3}, \mathrm{Mn}=15.5 \mathrm{mg} \mathrm{dm}^{-3}, \mathrm{Zn}=4.2 \mathrm{mg}$ $\mathrm{dm}^{-3}$, and $\mathrm{B}=0.3 \mathrm{mg} \mathrm{dm}^{-3}$. The area was tilled with a disk plow and disk harrow. The crop was planted on May 20,2013 at a density of 280,000 plants ha ${ }^{-1}$.

Both trials considered an area of $2100 \mathrm{~m}^{2}$ and were composed of three treatments and seven replications, using $9 \mathrm{~m}^{2}$ plots in a completely randomized design. The fertilizers chosen for the trials were $\mathrm{JK}^{\circledR}$ (Tables 1 and 2) and calda viçosa, a fertilizer composed of lime water, $\mathrm{CuSO}_{4}, \mathrm{ZnSO}_{4}, \mathrm{MnSO}_{4}$, and $\mathrm{H}_{3} \mathrm{BO}_{3}$, which is formulated according to the needs of each farmer.

Table 1 - Nutrients, $\mathrm{pH}$, and density contained in the organic foliar fertilizer JK ${ }^{\circledR}$

\begin{tabular}{lcc}
\hline Nutrient & Concentration & Unit \\
\hline Nitrogen & 2.20 & $\%$ \\
Phosphorus $\left(\mathrm{P}_{2} \mathrm{O}_{5}\right)$ & 1.05 & $\%$ \\
Potassium $\left(\mathrm{K}_{2} \mathrm{O}\right)$ & 0.20 & $\%$ \\
Calcium & 1.10 & $\%$ \\
Sulfur & 0.16 & $\%$ \\
Sodium & 0.14 & $\%$ \\
Organic Carbon & 23.10 & $\%$ \\
Magnesium & 425 & $\mathrm{ppm}$ \\
Iron & 100 & $\mathrm{ppm}$ \\
Manganese & 9 & $\mathrm{ppm}$ \\
Copper & 8 & $\mathrm{ppm}$ \\
Zinc & 30 & $\mathrm{ppm}$ \\
Boron & 90 & $\mathrm{ppm}$ \\
pH & 3.6 & $\mathrm{~g} \mathrm{~mL}$ \\
Density & 1.08 & \\
\hline
\end{tabular}


Table 2 - Amino acids contained in the organic foliar fertilizer JK®

\begin{tabular}{lc}
\hline Amino acid & $\%$ \\
\hline Aspartic Acid & 0.387 \\
Threonine & 0.246 \\
Serine & 0.279 \\
Glutamic Acid & 0.596 \\
Proline & 0.154 \\
Glycine & 0.575 \\
Alanine & 0.691 \\
Valine & 0.241 \\
Methionine & 0.210 \\
Isoleucine & 0.206 \\
Leucine & 0.458 \\
Tyrosine & 0.133 \\
Phenylalanine & 0.185 \\
Lysine & 0.380 \\
Ammonia & 0.071 \\
Histidine & 0.064 \\
Tryptophan & 0.090 \\
Arginine & 0.252 \\
\hline
\end{tabular}

In trial 1 , the following spray treatments were used: Control 1 = water; $\mathrm{FA}=\mathrm{JK} \AA$ amino acid-based foliar fertilizer; $\mathrm{FA}+\mathrm{Mi}=\mathrm{FA}+\mathrm{Mi}\left(\mathrm{CuSO}_{4}+\mathrm{ZnSO}_{4}+\mathrm{MnSO}_{4}\right.$ $\left.+\mathrm{H}_{3} \mathrm{BO}_{3}\right)$; and in trial 2: Control 2 = water; $\mathrm{CV}=$ calda viçosa, and $\mathrm{FA}+\mathrm{Mi}$. The rates of micronutrients added for composing FA+Mi were: $100 \mathrm{~g} \mathrm{ha}^{-1}$ of $\mathrm{CuSO}_{4}, 200$ $\mathrm{g} \mathrm{ha}^{-1}$ of $\mathrm{ZnSO}_{4}, 200 \mathrm{~g} \mathrm{ha}^{-1}$ of $\mathrm{MnSO}_{4}$, and $60 \mathrm{~g} \mathrm{ha}^{-1}$ of $\mathrm{H}_{3} \mathrm{BO}_{3}$, diluted in $2 \mathrm{~L} \mathrm{ha}^{-1}$ of FA. For preparation of calda viçosa, the micronutrients (the same amount used for FA) were diluted in $2 \mathrm{~L} \mathrm{ha}^{-1}$ of lime water ( 2 $\mathrm{L}$ of water $+100 \mathrm{~g}$ of non-hydrated lime). The treatments were sprayed three times with a backpack sprayer at the concentration of $0.2 \%$ - at 57 days after planting (DAP) at the third open trefoil stage, at 63 DAP at the flower budding stage, and at $71 \mathrm{DAP}$ at the pod formation stage. Bean plant leaves were sampled at $67 \mathrm{DAP}$ (flowering) for determination of $\mathrm{Fe}, \mathrm{Mn}, \mathrm{Cu}$, $\mathrm{B}$, and $\mathrm{Zn}$, as described in Malavolta et al. (1997).

The second part of the experiment was performed in the laboratory. Each one of the three fertilizers tested in the field was mixed with biological control agents for the purpose of evaluating their compatibility. For that reason, Bacillus thuringiensis was used as a test

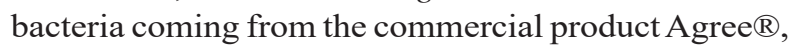
and Beauveria bassiana as a test fungus, coming from the commercial product Boveril ${ }^{\circledR}$.

For the tests with $B$. thuringiensis, $0.150 \mathrm{~g}$ of the commercial product in saline solution was added to the control treatment. For the FA treatment, $0.2 \mathrm{~mL}$ of the $\mathrm{JK}^{\circledR}$ was also added. For the FA+Mi treatment, in addition to the previous items, $35.5 \mathrm{mg}$ of $\mathrm{CuSO}_{4}$, $65 \mathrm{mg}$ of $\mathrm{ZnSO}_{4}, 65 \mathrm{mg}$ of $\mathrm{MnSO}_{4}$, and $20 \mathrm{mg}$ of $\mathrm{H}_{3} \mathrm{BO}_{3}$ were added. And for the $\mathrm{CV}$ treatment, in addition to the bacteria, $10 \mathrm{~mL}$ of lime water $+35.5 \mathrm{mg}$ of $\mathrm{CuSO}_{4}$, $65 \mathrm{mg}$ of $\mathrm{ZnSO}_{4}, 65 \mathrm{mg}$ of $\mathrm{MnSO}_{4}$, and $20 \mathrm{mg}$ of $\mathrm{H}_{3} \mathrm{BO}_{3}$ were added.

In the tests with $B$. bassiana, the treatments were the same, just as the quantities of FA, micronutrients, and lime water; however, the amount of commercial product added was $0.133 \mathrm{~g}$.

The concentrations of biological products were those recommended for the dry edible bean crop according to the product labels and adjusted for $100 \mathrm{~mL}$ of spray mix $(90 \mathrm{~mL}$ of saline solution $+10 \mathrm{~mL}$ of fertilizer solution). The treatments were diluted in $90 \mathrm{~mL}$ of saline solution, shaken, and left to rest for one hour for later dilution. The dilutions for $B$. thuringiensis used in plating were from $10^{-6}$ to $10^{-10}$, and for B. bassiana, they were from $10^{-5}$ to $10^{-9}$.

The culture medium used for $B$. thuringiensis was nutrient agar (NA), and for B. bassiana, it was potato dextrose agar (PDA) with pentabiotic. The $B$. thuringiensis plates remained in a laboratory oven at $30^{\circ} \mathrm{C}$ for 24 hours whereas the $B$. bassiana plates remained in BOD (Biological Oxygen Demand) at 28 ${ }^{\circ} \mathrm{C}$ for three days.

The colony forming units (CFU) were thus counted and the degree of compatibility was subsequently determined, simulating possible combined application of the products in the spray mix.

The results were subjected to analysis of variance and the mean values were compared by the Tukey test at $5 \%$.

\section{RESULTS AND DISCUSSION}

In trial 1, the application of FA+Mi resulted in leaf concentrations of $\mathrm{Mn}, \mathrm{Cu}$, and $\mathrm{Zn}$ that were $32 \%$, $57 \%$, and $52 \%$ higher, respectively, than the control (Table 3).

In trial 2, the application of FA+Mi and calda viçosa resulted in leaf concentrations of $\mathrm{Mn}, \mathrm{Cu}$, and $\mathrm{Zn}$ that were $59 \%, 67 \%$, and $54 \%$ higher, respectively, in the average of the $\mathrm{FA}+\mathrm{Mi}$ and calda viçosa treatments, than the control (Table 4). 
Table 3 - Micronutrient concentrations in the leaves of dry edible bean harvested at 67 days after planting in trial 1, with water (control), $\mathrm{FA}\left(\mathrm{JK}^{\circledR}\right.$ amino acid-based foliar fertilizer), and $\mathrm{FA}+\mathrm{Mi}\left(\mathrm{FA}+\mathrm{CuSO}_{4}\right.$ $\left.+\mathrm{ZnSO}_{4}+\mathrm{MnSO}_{4}+\mathrm{H}_{3} \mathrm{BO}_{3}\right)$

\begin{tabular}{|c|c|c|c|c|c|}
\hline Treatment & $\mathrm{Fe}$ & $\mathrm{Mn}$ & $\mathrm{Cu}$ & $\mathrm{Zn}$ & B \\
\hline & & & \multicolumn{3}{|l|}{$\mathrm{mg} \mathrm{kg}^{-1}$} \\
\hline Water & $297.43 \mathrm{a}$ & $53.29 \mathrm{~b}$ & $16.14 \mathrm{c}$ & $40.00 \mathrm{~b}$ & $23.09 \mathrm{a}$ \\
\hline FA & $321.00 \mathrm{a}$ & $55.43 \mathrm{~b}$ & $18.29 \mathrm{~b}$ & $42.86 \mathrm{~b}$ & $23.97 \mathrm{a}$ \\
\hline $\mathrm{FA}+\mathrm{Mi}$ & $295.86 \mathrm{a}$ & $70.14 \mathrm{a}$ & $25.29 \mathrm{a}$ & $60.71 \mathrm{a}$ & $23.63 \mathrm{a}$ \\
\hline CV $(\%)$ & 10.50 & 11.36 & 7.27 & 7.88 & 10.02 \\
\hline
\end{tabular}

Mean values followed by the same letter in the column do not differ among themselves at $5 \%$ significance by the Tukey test. CV (\%) is the coefficient of variation.

Table 4 - Micronutrient concentrations in the leaves of dry edible bean harvested at 67 days after planting in trial 2, with water (control), Calda Viçosa and FA $+\mathrm{Mi}\left(\mathrm{JK}^{\circledR}\right.$ amino acid-based foliar fertilizer $+\mathrm{CuSO}_{4}$ $\left.+\mathrm{ZnSO}_{4}+\mathrm{MnSO}_{4}+\mathrm{H}_{3} \mathrm{BO}_{3}\right)$

\begin{tabular}{lccccc}
\hline Treatment & $\mathrm{Fe}$ & $\mathrm{Mn}$ & $\mathrm{Cu}$ & $\mathrm{Zn}$ & \\
\hline & \multicolumn{1}{c}{$\mathrm{mg} \mathrm{kg}^{-1}$} & $10.90 \mathrm{~b}$ & $40.84 \mathrm{~b}$ & $\mathrm{~B}$ \\
\cline { 2 - 5 } Water & $203.79 \mathrm{a}$ & $39.06 \mathrm{~b}$ & $18.33 \mathrm{a}$ & $61.81 \mathrm{a}$ & $33.33 \mathrm{a}$ \\
Calda Viçosa & $201.86 \mathrm{a}$ & $61.29 \mathrm{a}$ & $17.94 \mathrm{a}$ & $63.59 \mathrm{a}$ & $34.43 \mathrm{a}$ \\
FA+Mi & $212.46 \mathrm{a}$ & $62.36 \mathrm{a}$ & 13.40 & 15.29 & $43.10 \mathrm{a}$ \\
$\mathrm{CV}(\%)$ & 11.91 & 17.06 & & 49 \\
\hline
\end{tabular}

Mean values followed by the same letter in the column do not differ among themselves at $5 \%$ significance by the Tukey test. CV(\%) is the coefficient of variation.

Thus, the FA+Mi is equal to calda viçosa in regard to supplying nutrients through the leaf. It was expected that the supply of nutrients by FA+Mi would be greater than in calda viçosa due to a possible interaction (chelation) between the micronutrients added to the mix and the amino acids of the fertilizer (Lucena, 2009; Ghasemi, 2012). However, this could not be expressed in the results obtained since this benefit is observed by greater speed of nutrient uptake, which avoids nutrient losses; this prevention of losses was not detected up to the time of collecting leaves for analysis. At any rate, the supply of these micronutrients was satisfactory and these values were similar to those found through the use of different combinations of calda viçosa itself (Aquino et al., 2008; Androcioli et al., 2012; Carvalho et al., 2012).

Boric acid added to the $\mathrm{FA}+\mathrm{Mi}$ did not result in higher leaf concentrations of $\mathrm{B}$ in relation to the control in either of the two trials. The same was observed with calda viçosa. That shows that there was no leaf absorption of the element by the plants. In some situations, antagonism or synergism during leaf absorption can occur between the elements B and $\mathrm{Zn}$ when they are applied in the form of boric acid and zinc sulfate. This occurrence can vary according to the application rate, nutrient contents available in the soil, and the source of the fertilizer (Aref, 2010; Silva et al., 2014).

In trial 1, the application with FA resulted in a higher $\mathrm{Cu}$ concentration in the leaves (Table 3 ), which was $13 \%$ greater than in the control. $\mathrm{Cu}$ is a constituent of tyrosinase (an enzyme abundant in the chloroplast cell walls and membranes), which participates in oxidation of tyrosine (Festa \& Thiele, 2011; Marschner, 2012). Tyrosine is an amino acid component of FA, so it may have led to the higher concentration of $\mathrm{Cu}$ found in the leaves (Perotti et al., 2010). Consequently, this micronutrient may be supplied by the FA at a lower amount, even without the addition of copper sulfate. If the objective of management operations is to supply the nutrient and, in addition, stimulate the microorganisms in the spray mixture, this may be an interesting alternative because $\mathrm{Cu}$ is known to be an element that at high concentrations may have a bactericidal and fungicidal effect (Smith \& Collins, 2007; Antoniolli et al., 2010). 
In the trial of compatibility of the products with the biological control agents, similar results were obtained both for the fungus and for the bacteria tested (Figures 1 and 2).

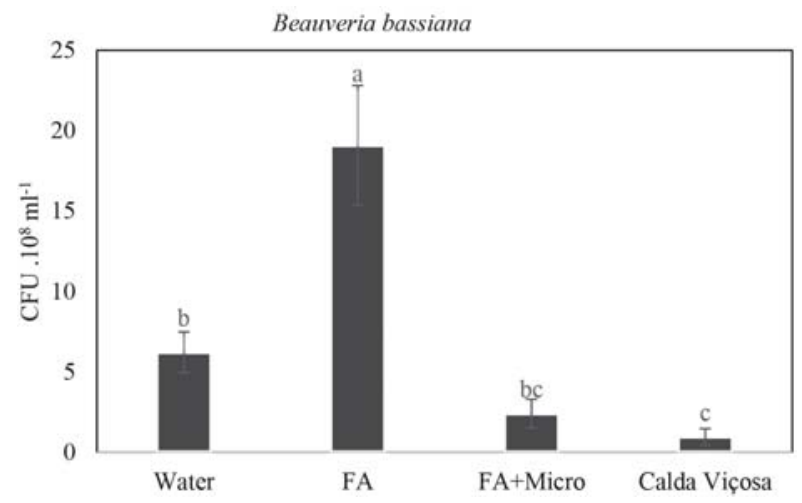

Figure 1 - Colony forming units (CFU) obtained from plate count in the test of compatibility with Beauveria bassiana with water, amino acidbased fertilizer (FA), FA with the addition of $\mathrm{CuSO}_{4}+\mathrm{ZnSO}_{4}+\mathrm{MnSO}_{4}+\mathrm{H}_{3} \mathrm{BO}_{3}$ $(\mathrm{FA}+\mathrm{Mi})$, and calda viçosa.

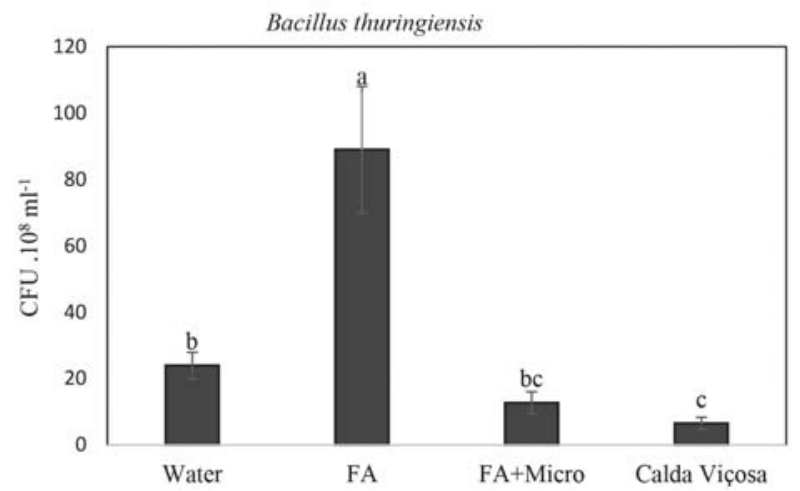

Figure 2 - Colony forming units (CFU) obtained from plate count in the test of compatibility with Bacillus thuringiensis with water, amino acid-based fertilizer (FA), FA with the addition of $\mathrm{CuSO}_{4}+\mathrm{ZnSO}_{4}+\mathrm{MnSO}_{4}+\mathrm{H}_{3} \mathrm{BO}_{3}$ (FA+Mi), and calda viçosa.

The mixture of FA+Mi with the B. bassiana fungusbased commercial product or the mixture of $\mathrm{FA}+\mathrm{Mi}$ with the $B$. thuringiensis bacteria-based commercial product did not show a difference in relation to the control to which only water was added. However, the mixture of FA alone with either of the two products clearly stimulated the growth of both bacterial and fungal colonies. Thus, we observed that the addition of micronutrients to the mixture inhibited this stimulus. From the results obtained, it can be deduced that adding the micronutrients to the mixture hurt microorganism growth. However, the addition of FA may have mitigated the action of the micronutrients harmful to microorganism growth. The influence of $\mathrm{pH}$ level, of the concentration of chemical elements, and of the type of chemical element on microorganisms is already well known (Thies \& Grossman, 2006). Contact with large concentrations of some trace elements can inhibit the growth of colonies (Nogueira \& Soares, 2010). The stimulant effect caused by the FA is certainly due to its composition. This product, in addition to being rich in amino acids, passes through a fermentation process with the addition of molasses, and there are diverse carbohydrates in its composition. These carbohydrates, together with amino acids, serve as food for microorganisms, benefitting the bacterium and the fungus tested, exhibiting vast stimulant potential. Colony growth was an average of 3.7 times greater in B. thuringiensis and 3 times greater in B. bassiana. However, more tests would be required to verify whether this biostimulation would result in better plant health results by the products.

Results obtained from the mixture of calda viçosa with the two entomopathogens were similar in regard to the growth of colony forming units. In both cases, the calda viçosa limited the growth of the microorganisms. The mixture with calda viçosa resulted in average growth of $B$. thuringiensis that was only $27 \%$ of growth without calda viçosa, and the average growth of $B$. bassiana was only $15 \%$ of growth without calda viçosa. Calda viçosa (fungicide and bactericide) proved to be an option of low compatibility in this study (Kimati, 1995; Chalfoun et al., 2007).

The results found in this study suggest some management options with the use of the mixtures analyzed. If the aim is to supply $\mathrm{Zn}, \mathrm{Cu}$, and $\mathrm{Mn}$, and if there is the intention or need to use bacteria or fungi as biological control in the same operation, the use of FA together with the micronutrient mix is recommended. If the intention is to biostimulate the microorganisms involved, use of FA without the micronutrients is recommended, and it is still possible to supply $\mathrm{Cu}$ to 
the crop in smaller proportions. If the need is to supply $\mathrm{Zn}, \mathrm{Cu}$, and $\mathrm{Mn}$, but without the addition of microorganisms, calda viçosa is efficient in supplying micronutrients, and there is potential for control of some plant diseases (Schwengber et al., 2007).

\section{CONCLUSIONS}

Amino acid-based fertilizer with the addition of micronutrients raised the concentrations of $\mathrm{Zn}, \mathrm{Cu}$, and $\mathrm{Mn}$ in the plant in a manner similar to calda viçosa. Nevertheless, none of the options tested were effective in supplying B. Calda viçosa proved to be incompatible with $B$. bassiana and with $B$. thuringiensis when mixed with the spray for application, whereas amino acidbased fertilizer with the addition of micronutrients did not exhibit incompatibility as the water control treatment, although did not differ from Calda Viçosa. Thus, this proposal can be an interesting alternative for organic agriculture.

\section{ACKNOWLEDGMENTS}

The authors thank JK Fertilizante for the supply of the organic fertilizer.

\section{CITED LITERATURE}

ANDROCIOLI, H.G.; MENEZES JÚNIOR, A.O.; HOSHINO, A.T. et al. Produtos alternativos no controle da Hemileia vastatrix (Berkeley \& Broome) e Cercospora coffeicola (Berkeley \& Cooke) em cafeeiros. Coffee Science, v.7, n.2, p.187-197, 2012.

ANTONIOLLI, Z.I.; SANTOS, L.C.; LUPATINI, M. et al. Efeito do cobre na população de bactérias e fungos do solo, na associação micorrízica e no cultivo de mudas de Eucalyptus grandis W. Hill ex Maiden, Pinus elliottii Engelm e Peltophorum dubium (Sprengel) Taubert. Ciência

Florestal, v.20, n.3, p.419-428, 2010.

AQUINO, L.A.; BERGER, P.G.; RODRIGUES, F.A. et al. Controle alternativo da mancha de Ramularia do algodoeiro. Summa Phytopathology, v.34, n.2, p.131-136, 2008.

AREF, F. Application of different levels of zinc and boron on concentration and uptake of zinc and boron in the corn grain. Journal of American Science, v.6, n.5, p.100-106, 2010.
BRASIL. Em um ano, total de produtores orgânicos cresce $51 \%$. Ministério da Agricultura Pecuária e Abastecimento, 2015. In: http://www.brasil.gov.br/ economia-e-emprego/2015/03/em-um-ano-total-deprodutores-organicos-cresce-51 (accessed on 13 October 2016).

CARVALHO JÚNIOR, L.C.; HAUFFE, P. Motivações para a certificação na produção de alimentos orgânicos no estado de Santa Catarina. Revista Cadernos de Economia, v. 17, n.32, p.40-51, 2013.

CARVALHO, V.L.; CUNHA, R.L.; SILVA, N.R.N. Alternativas de controle de doenças do cafeeiro. Coffee Science, v.7, n.1, p.42-49, 2012.

CHALFOUN, S.M.; CUNHA, R.L.; CARVALHO, V.L. et al. Seletividade de fungicidas cúpricos e sistêmicos sobre o fungo Cladosporium cladosporioides em cafeeiro. Summa Phytopathology, v.33, n.1, p.93-95, 2007.

DIAS, V.V.; SCHULTZ, G.; SCHUSTER, M.S. et al. O mercado de alimentos orgânicos: um panorama quantitativo e qualitativo das publicações internacionais. Ambiente \& Sociedade, v.XVIII, n.1, p.161-182, 2015.

EMBRAPA. Centro Nacional de Pesquisa de Solos. Sistema Brasileiro de

Classificação de Solos. 2 ed. Rio de Janeiro: Embrapa Solos, 2006. 306p.

FESTA, R.A.; THIELE, D.J. Copper: an essential metal in biology. Current Biology, v.21, n.21, p.877-883, 2011.

GHASEMI, S.; KHOSHGOFTARMANESH, A.H.; AFYUNI, M. et al. The effectiveness of foliar applications of synthesized zinc-amino acid chelates in comparison with zinc sulfate to increase yield and grain nutritional quality of wheat. European Journal of Agronomy, v.45, p.68-74, 2012.

KIMATI, H. Controle Químico. In: BERGAMIN FILHO, A.; KIMATI, H.; AMORIN, L. Manual de Fitopatologia. 3. ed. São Paulo: Agronômica Ceres, 1995. p.770-771. 
LUCENA, J.J. El empleo de complejantes y quelatos en la fertilización de micronutrientes. Revista Ceres, v.56, n.4, p.527-535, 2009.

MALAVOLTA, E.; VITTI, G.C.; OLIVEIRA, A.O. Avaliação do estado nutricional das plantas: princípios e aplicações. 2. ed. Piracicaba: Potafos, 1997.319p.

MARSCHNER, H. Mineral Nutrition of Higher Plants. 3. ed. Germany: University of Hohenheim, Institute of Plant Nutrition, 2012. 649 p.

MONTALBA, R; ARRIAGADA, C.; ALVEAR, M. et al. Effects of conventional and organic nitrogen fertilizers on soil microbial activity, mycorrhizal colonization, leaf antioxidant content, and Fusarium wilt in highbush blueberry (Vaccinium corymbosum L.).

Scientia Horticulturae, v. 125, n.4, p.775778, 2010.

NEWTON, A.C.; GRAVOUIL, C.; FOUNTAINE, J.M. Managing the ecology of foliar pathogens: ecological tolerance in crops. Annals of Applied Biology, v.157, n.3, p.343-359, 2010.

NIX-STOHR, S.; BURPEE, L.L.; BUCK, J.W. The influence of exogenous nutrients on the abundance of yeasts on the phylloplane of turfgrass. Microbial Ecology, v.55, p.15-20, 2007.

NOGUEIRA, M.A.; SOARES, C.R.F.S. Micorrizas arbusculares e elementos-traço. In: SIQUEIRA, J.O.; SOUZA, F.A.; CARDOSO, E.J.B.N. et al. (Eds.). Micorrizas: 30 anos de pesquisa no Brasil. Lavras: UFLA, 2010. p.475-501.
PEROTTI, J.C.; RODRIGUES, I.C.S.; KLEINOWSKI, A.M. et al. Produção de betacianina em erva-dejacaré cultivada in vitro com diferentes concentrações de sulfato de cobre. Ciência Rural, v.40, n.9, p.1874-1880, 2010.

POZZEBON, A.; BORGO, M.; DUSO, C. The effects of fungicides on non-target mites can be mediated by plant pathogens. Chemosphere, v.79, n.1, p.8-17, 2010.

RAIJ, B. van; ANDRADE, J.C.; CANTARELLA, H. et al. Análise química para avaliação da fertilidade de solos tropicais. Campinas: Secretaria de Agricultura e Abastecimento, APTA e IAC, 2001. 284p.

SCHWENGBER, J.E.; SCHIEDECK, G.; GONÇALVES, M.M. Preparo e utilização de caldas nutricionais e protetoras de plantas. Embrapa Clima Temperado: Pelotas, 2007. 62p. Available at: http://www.infoteca.cnptia.embrapa.br/bitstream/ doc/ 745636/1/cart49806.pdf.

SILVA, A.A.; COUTO JUNIOR, P.A.; LANA, A.M.Q. et al. Teores de micronutrientes no solo e foliar com aplicação de fontes quelatadas e sulfatadas em feijão. Engenharia Agrícola, v.34, n.1, p.28-27, 2014.

SMITH, J.L.; COLLINS, P. Management of organisms and their processes in soils. In: PAUL, E.A. (Eds.). Soil Microbiology, Ecology, and Biochemistry, 3. ed. Oxford: Elsevier Academic Press, 2007. p.471-500.

THIES, J.E.; GROSSMAN, J.M. The soil habitat and soil ecology. In: UPHOFF, N.; BALL, A.; FERNANDES, E. et al. (Eds.). Biological Approaches to Sustainable Soil Systems. Boca Raton: CRC Press, 2006. p.59-78.

Recebido para publicação em 13/4/2017 e aprovado em 4/9/2017 